\title{
GAMBARAN PARITAS PADA IBU YANG MEMILIKI BALITA STUNTING DI DESA CIKUNIR KECAMATAN SINGAPARNA KABUPATEN TASIKMALAYA TAHUN 2019
}

\author{
Hapi Apriasih, SST., M.Kes \\ py.anbyan@gmail.com \\ Reynalda Aprilia D \\ Prodi DIII Kebidanan Sekolah Tinggi Ilmu Kesehatan Respati Tasikmalaya \\ Jl. Raya Singaparna KM 11 Cikunir, Kab Tasikmalaya Indonesias,
}

\section{A. ABSTRAK}

Kejadian balita pendek atau biasa disebut dengan stunting merupakan masalah gizi utama yang dihadapi Indonesia saat ini, data RISKESDAS menunjukkan bahwa prevalensi balita stunting pada 2018 mencapai 30,8 persen. Hal ini menunjukkan bahwa Indonesia sedang mengalami masalah kesehatan masyarakat yang berat dalam kasus balita stunting, wilayah kerja Puskesmas Singaparna termasuk kedalam zona merah stunting. Tujuan dari penelitian ini adalah mengetahui gambaran paritas dari ibu yang memiliki balita stunting di Desa Cikunir Kabupaten Tasikmalaya Tahun 2019.

Metode penelitian yang digunakan dalam penelitian ini adalah deskriptif untuk menggambarkan paritas pada ibu yang memiliki balita dengan stunting. Populasi adalah semua semua ibu yang memiliki balita dengan stunting sebanyak 139 orang, dengan total sampling. Waktu penelitian dilaksanakan pada bulan Maret s.d April 2019, bertempat di Desa Cikunir Kecamatan Singaparna Kab Tasikmalaya Tahun 2019. Prosedur pengambilan data dilakukan dengan data primer yaitu diperoleh dengan survey langsung kepada responden ibu yang memiliki balita stunting dan dianalisis dengan distribusi frekuensi dalam bentuk table.

Hasil penelitian menunjukan bahwa dari 139 orang ibu yang memiliki balita dengan stunting adalah dengan paritas primipara (jumlah anak 1) sebanyak 35 orang (25\%), paritas multipara (jumlah anak 1-4) sebanyak 86 orang (62\%) dan paritas grande mulitapara (lebih dari 4) sebanyak 18 orang (13\%).

Simpulan dari penelitian ini adalah kejadian balita stunting tidak terlepas dari status paritas ibu dimana semakin banyak ibu memiliki anak semakin besar peluang terjadinya kejadian stunting pada anak yang dapat diakibatkan oleh faktor pola pemberian makan, ataupun pola asuh dikeluarga, sehingga diharapkan para bidan dapat membantu ibu dalam upaya membatasi jumlah anak yaitu dengan penggunaan alat kontrasepsi.

Kata Kunci : Paritas, BalitaStunting

Kepustakaan : $15(2012-2017)$ 


\section{B. PENDAHULUAN}

Indonesia saat ini merupakan negara dengan beban stunting pada anak tertinggi ke-2 di kawasan Asia Tenggara. Sementara di dunia menempati posisi nomor 5. Data RISKESDAS menunjukkan bahwa prevalensi balita stunting pada 2018 mencapai 30,8 persen. Itu artinya, satu dari tiga balita mengalami perawakan pendek akibat malanutrisi kronis. Hal ini menunjukkan bahwa Indonesia sedang mengalami masalah kesehatan masyarakat yang berat dalam kasus balita stunting. ${ }^{1}$

Stunting merupakan salah satu target Sustainable Development Goals (SDGs) yang termasuk pada tujuan pembangunan berkelanjutan ke-2 yaitu menghilangkan kelaparan dan segala bentuk malnutrisi pada tahun 2030 serta mencapai ketahanan pangan. Target yang ditetapkan adalah menurunkan angka stunting hingga 40\% pada tahun $2025 .^{2}$

Masalah kurang gizi dan stunting merupakan dua masalah yang saling berhubungan. Stunting pada anak merupakan dampak dari defisiensi nutrien selama seribu hari pertama kehidupan. Hal ini menimbulkan gangguan perkembangan fisik anak yang irreversible, sehingga menyebabkan penurunan kemampuan kognitif dan motorik serta penurunan performa kerja. Anak stunting memiliki rerata skor Intelligence Quotient (IQ) sebelas poin lebih rendah dibandingkan rerata skor IQ pada anak normal. Gangguan tumbuh kembang pada anak akibat kekurangan gizi bila tidak mendapatkan intervensi sejak dini akan berlanjut hingga dewasa.

Stunting pada balita perlu mendapatkan perhatian khusus karena dapat menyebabkan terhambatnya pertumbuhan fisik, perkembangan mental dan status kesehatan pada anak. Studi terkini menunjukkan anak yang mengalami stunting berkaitan dengan prestasi di sekolah yang buruk, tingkat pendidikan yang rendah dan pendapatan yang rendah saat dewasa. Kasus stunting pada anak dapat dijadikan prediktor rendahnya kualitas sumber daya manusia suatu negara. Keadaan stunting menyebabkan buruknya kemampuan kognitif, rendahnya produktivitas, serta meningkatnya risiko penyakit mengakibatkan kerugian jangka panjang bagi ekonomi Indonesia.

Banyak upaya yang dapat dilakukan untuk pencegahan stunting selain asupan gizi yang seimbang yaitu dengan mengikuti program keluarga berencana untuk dapat membatasi jumlah kelahiran dimana jumlah anak menjadi salah satu faktor penyebab atau resiko yang dapat menyebabkan stunting. ${ }^{3}$

Daerah Kabupaten Tasikmalaya yang memiliki kejadian stunting cukup tinggi 
salah satunya adalah kecamatan Singaparna. Angka prevalensi stunting di Kecamatan Singaparna dari tahun 2016 hingga tahun 2018 tidak mengalami penurunan yaitu mencapai 933 kasus $(23,9 \%)$. Kecamatan Singaparna memiliki dua puskesmas yaitu Puskesmas Tinewati dan Puskesmas Singaparna. Puskesmas Tinewati terdapat 362 kasus stunting sedangkan Puskesmas Singaparna mencapai 571 kasus. Sedangkan target nasional mengenai prevalensi stunting adalah kurang dari $20 \%$ sehingga wilayah kerja Puskesmas Singaparna termasuk kedalam zona merah stunting (Laporan Hasil BPB Kab. Tasikmalaya, 2016, 2017 , 2018).

Wilayah kerja Puskesmas Singaparna terdiri dari 5 (lima) desa yaitu Desa Singaparna, Sukamulya, Cintaraja, Cikunir, dan Cikadongdong. Adapun kejadian stunting pada usia 0 - 59 bulan di wilayah kerja puskesmas singaparna dapat diurutkan dari yang paling banyak yaitu Desa Cintaraja (175 kasus), Desa Cikunir (139 kasus), Desa Singaparna (127 kasus), dan Desa Cikadongdong (66 kasus) (Laporan Hasil BPB Puskesmas Singaparna, 2018). Berdasarkan data tersebut bahwa kejadian stunting di Desa Cikunir yang merupakan desa binaan STIKes Respati merupakan desa kedua tertinggi dengan kejadin stunting oleh karena itu penulis bermaksud melakukan penelitian dengan judul gambaran paritas pada ibu yang memiliki balita stunting di Desa Cikunir Kecamatan Singaparna Kab Tasikmalaya Tahun 2019.

\section{TINJAUAN PUSTAKA}

Stunting adalah kondisi gagal tumbuh pada anak balita (Bagi bayi dibawah lima tahun) yang diakibatkan kekurangan gizi kronis sehingga anak terlalu pendek untuk usianya. Kekurangan gizi terjadi sejak bayi dalam kandungan dan pada masa awal setelah bayi lahir, akan tetapi kondisi stunting baru Nampak setelah bayi berusia 2 tahun. ${ }^{4}$

Stunting ditandai dengan tinggi badan kurang menurut umur (<-2SD), ditandai dengan melambatnya pertumbuhan anak yang mengakibatkan kegagalan dalam mencapai tinggi badan yang normal dan sehat sesuai usia anak. Stunting merupakan kekurangan gizi kronis atau kegagalan pertumbuhan dimasa lalu dan digunakan sebagai indikator jangka panjang. ${ }^{5}$

Penyebab stunting terdiri dari penyebab langsung dan tidak langsung. Gizi ibu sebelum dan selama kehamilan merupakan penyebab tidak langsung yang memberikan kontribusi terhadap perkembangan dan pertumbuhan janin. Dan penyebab langsung yaitu asupan makanan tidak seimbang yang berkaitan dengan kandungan zat gizi dalam 
makanan yaitu (ASI) secara eksklusif, tidak menerima makanan pendamping Air Susu Ibu (MP-ASI). ${ }^{5}$

Faktor faktor yang terkait dengan kejadian stunting diantaranya dilihat dari karakteristik orangtua yaitu pendidikan, pekerjaan, pendapatan, pola asuh, pola makan, jumlah anak dalam keluarga dan faktor yang berkaitan dengan kesehatan. ${ }^{5}$

Kejadian stunting selalu dikaitkan dengan pemenuhan pola nutrisi pada balita dimana asupan nutrisi yang baik akan dapat memberikan dampak yang baik pada balita sehingga balita dapat tumbuh dengan sehat dan berkembang dengan baik, namun pemenuhan nutrisi tersebut tidak lepas dari kondisi dalam keluarga dimana tidak semua keluarga dapat memenuhi asupan yang baik pada anaknya terutama jika dikaitkan dengan jumlah anggota keluarga, jumlah keluarga berpengaruh dalam pemenuhan nutrisi dalam keluarga apalagi ditunjang dengan kondisi ekonomi dalam keluarga tersebut, sejalan dengan penelitian ayu Chandra rata-rata kejadian stunting terjadi pada jumlah anggota keluarga yang lebih dari 2, keluarga yang memiliki banyak anak terutama dengan kondisi ekonomi kurang tidak akan dapat memberikan perhatian dan makanan yang cukup pada seluruh keluarganya. ${ }^{6}$

Berbagai upaya dapat dilakukan untuk mencegah terjadinya stunting yaitu berdasarkan Peraturan Menteri Kesehatan
Nomor 39 Tahun 2016 tentang Pedoman Penyelenggaraan Program Indonesia Sehat dengan Pendekatan Keluarga, upaya yang dilakukan untuk menurunkan prevalensi stunting di antaranya sebagai berikut pada Ibu Hamil dan Bersalin a. Intervensi pada 1.000 hari pertama kehidupan; b. Mengupayakan jaminan mutu ante natal care (ANC) terpadu; c. Meningkatkan persalinan di fasilitas kesehatan; $d$. Menyelenggarakan program pemberian makanan tinggi kalori, protein, dan mikronutrien (TKPM); e. Deteksi dini penyakit (menular dan tidak menular); f. Pemberantasan kecacingan; g. Meningkatkan transformasi Kartu Menuju Sehat (KMS) ke dalam Buku KIA; h. Menyelenggarakan konseling Inisiasi Menyusu Dini (IMD) dan ASI eksklusif; dan i. Penyuluhan dan pelayanan KB. Pada Balita a. Pemantauan pertumbuhan balita; $b$. Menyelenggarakan kegiatan Pemberian Makanan Tambahan (PMT) untuk balita; c. Menyelenggarakan stimulasi dini perkembangan anak; dan d. Memberikan pelayanan kesehatan yang optimal. Pada Anak Usia Sekolah a. Melakukan revitalisasi Usaha Kesehatan Sekolah (UKS); b. Menguatkan kelembagaan Tim Pembina UKS; c. Menyelenggarakan Program Gizi Anak Sekolah (PROGAS); dan d. Memberlakukan sekolah sebagai kawasan bebas rokok dan narkoba. Pada Remaja a. Meningkatkan penyuluhan untuk 
perilaku hidup bersih dan sehat (PHBS), pola gizi seimbang, tidak merokok, dan mengonsumsi narkoba; dan b. Pendidikan kesehatan reproduksi. Pada Dewasa Muda a. Penyuluhan dan pelayanan keluarga berencana $(\mathrm{KB})$; b. Deteksi dini penyakit (menular dan tidak menular); dan c. Meningkatkan penyuluhan untuk PHBS, pola gizi seimbang, tidak merokok/mengonsumsi narkoba. ${ }^{2}$

Dari berbagai upaya yang dilakukan berdasarkan peraturan menteri kesehatan bahwa terdapat upaya pencegahan stunting yaitu dengan penyuluhan dan pelayanan Keluarga Berencana, dan relevan dengan berbagai hasil penelitian yang mengatakan bahwa salah satu penyebab kejadian stunting adalah jumlah anak yang banyak maka peran tenaga kesehatan bagaimana meningkatkan penyuluhan dan pelayanan keluarga berencana pada setiap ibu dan wanita dewasa, maka peran keluarga berencana sangat penting dalam mencegah kejadian stunting pada balita.

\section{METODE PENELITIAN}

Metode penelitian yang digunakan dalam penelitian ini adalah deskriptif untuk menggambarkan paritas pada ibu yang memiliki balita dengan stunting.

Populasi adalah semua semua ibu yang memiliki balita dengan stunting sebanyak 139 orang, dengan total sampling.
Waktu penelitian dilaksanakan pada bulan Maret s.d April 2019, bertempat di Desa Cikunir Kecamatan Singaparna Kab Tasikmalaya Tahun 2019.

Prosedur pengambilan data dilakukan dengan data primer yaitu diperoleh dengan survey langsung kepada responden ibu yang memiliki balita stunting

Adapun pengolahan dan analisis data dengan menggunakan data univariat dan dianalisis dengan distribusi frekuensi dalam bentuk tabel

\section{HASIL PENELITIAN DAN PEMBAHASAN}

Berdasarkan hasil penelitian yang telah dilaksanakan di Desa Cikunir Kecamatan Singaparna Kabupaten tasikmalaya Tahun 2019 pada ibu yang memiliki balita stunting dapat digambarkan sebagai berikut:

Tabel 4.1 Distribusi Frekuensi Paritas Ibu Yang Memiliki Balita Stunting Di Desa Cikunir Kecamatan Singaparna Kabupaten Tasikmalaya Tahun 2019

\begin{tabular}{lcc}
\hline Kategori & Frekuensi Persentase \\
\hline Primipara & 35 & 25 \\
Multipara & 86 & 62 \\
Grandemultipar & 18 & 13 \\
a & & \\
Jumlah & 139 & 100 \\
\hline
\end{tabular}

Tabel 4.1 menunjukkan sebagian besar paritas responden ada pada kategori lebih 
dari 1 yaitu multipara sebanyak 62 orang $(62 \%)$

Berdasarkan data diatas bahwa sebagian besar paritas ibu yang memiliki balita stunting adalah telah memiliki anak lebih dari satu, jumlah anggota keluarga dapat mempengaruhi pada alokasi pendapatan keluarga dalam memenuhi kebutuhan gizi keluarganya, dengan sumber daya yang terbatas, termasuk bahan makanan harus dibagi rata kepada semua anak dan terjadi persaingan sarana-prasarana, perbedaan makanan, dan waktu perawatan anak berkurang, memiliki anak terlalu banyak juga menyebabkan kasih sayang orang tua pada anak terbagi, jumlah perhatian yang diterima per anak menjadi berkurang, dan diperburuk jika status ekonomi keluarga tergolong rendah.

Pada penelitian ini didapatkan bahwa jumlah anak yang banyak akan berpengaruh terhadap tingkat konsumsi makanan, yaitu jumlah dan distribusi makanan dalam rumah tangga. Dengan jumlah anak yang banyak diikuti dengan distribusi makanan yang tidak merata akan menyebabkan anak balita dalam keluarga tersebut menderita kurang gizi. Jumlah anak yang banyak pada keluarga meskipun keadaan ekonominya cukup akan mengakibatkan berkurangnya perhatian dan kasih sayang orang tua yang di terima anaknya, terutama jika jarak anak yang terlalu dekat, dan dalam hal memenuhi kebutuhan makanan ibu akan bingung dalam memberikan makanan jika anaknya banyak karena fokus perhatiannya akan terbagi-bagi karena pasti anak balita mempunyai masalah dalam makan mungkin anak yang satunya nafsu makannya baik, tetapi yang lainnya tidak, maka ibu akan bingung mencari cara untuk memberi makan anak. Hal ini dapat berakibat turunnya nafsu makan anak sehingga pemenuhan kebutuhan primer anak seperti konsumsi makanannya akan terganggu dan hal tersebut akan berdampak terhadap status gizi anaknya. Sejalan dengan penelitian bahwa balita dari keluarga dengan jumlah anggota rumah tangga banyak cenderung mengalami stunting dibandingkan balita dari keluarga dengan jumlah anggota rumah tangga cukup. Balita dari keluarga dengan jumlah anggota rumah tangga banyak lebih berisiko 1.34 kali mengalami stunting dibandingkan dengan balita dari keluarga dengan jumlah anggota rumah tangga cukup. ${ }^{15}$

Banyak cara yang dapat dilakukan untuk mencegah terjadinya stunting dimulai dari upaya preventif yaitu bagaimana mempersiapkan para ibu muda bahkan dari masa remaja untuk dapat memahami konsep kehidupan berkeluarga, bagaimana mempersiapkan anak-anaknya kelak menjadi generasi penerus bangsa yang sehat dan kuat sehingga tidak ada anak-anak yang dilahirkan dengan kondisi stunting, mengenalkan program keluarga berencana 
agar dapat merencanakan jumlah anggota keluarganya dengan baik dengan penggunaan kontrasepsi yang sesuai, dan semua itu tentu tidak lepas dari peran tenaga kesehatan yang harus selalu meningkatkan pengetahuan dan keterampilannya sehingga dapat mengajak masyarakat terutama para remaja dan ibu untuk memahami bagaimana mencegah kejadian stunting.

\section{E. SIMPULAN DAN SARAN}

Simpulan dari penelitian ini adalah kejadian balita stunting tidak terlepas dari status paritas ibu dimana semakin banyak ibu memiliki anak semakin besar peluang terjadinya kejadian stunting pada anak yang dapat diakibatkan oleh faktor pola pemberian makan, ataupun pola asuh dikeluarga, sehingga diharapkan para bidan dapat membantu ibu dalam upaya membatasi jumlah anak yaitu dengan penggunaan alat kontrasepsi.

\section{F. REFERENSI}

1. RISKESDAS. Prevalensi kejadian Stunting Tahun 2018. In: ; 2018.

2. Pusat Data dan Informasi Kemenkes RI. Situasi Balita Pendek (Stunting) di Indonesia. Semester 1. Jakarta: Pusat Data dan informasi; 2018. doi:10.1017/CBO9781107415324.00 4
3. Banjarnahor ERD, Fathorrazi M, Sarwedi. Pengaruh faktor pendapatan keluarga , pendidikan ibu , jumlah anak dan pemanfaatan fasilitas kesehatan terhadap status gizi balita di desa Gunung Sari kecamatan Maesan kabupaten Bondowoso. Artik Ilm Mhs. 2015:1-4. file:///D:/PENELITIAN DAN ABDIMAS/Jurnal Jumlah anak dan Status Gizi/EVA ROSANA DORALITA

BANJARNAHOR.pdf\%0D.

4. Kemenkes RI. Info Datin Situasi dan Analisis Gizi. Jakarta: Kemenkes RI Pusat Data dan informasi; 2015.

5. nul, bawon H \& yuliana W. Darurat Stunting dengan Melibatkan Keluarga. 1 ed. Sulawesi Selatan: Yayasan Ahmar Cendekia Indonesia; 2019.

6. Aryu Candra. Hubungan Underlying Factors Dengan Kejadian Stunting Pada Anak 1-2 Th. Hub Underlying Factors Dengan Kejadian Stunting Pada Anak 1-2 Th. 2013;1(1). doi:10.14710/jnh.1.1.2013.\%p

7. Manzilati A. Paradigma Metode dan Aplikasi. (Press TU, ed.). Malang: UB Media, Universitas Brawijaya Press; 2017.

8. Dila K. Telaah Kritis Artikel Review Sistematik Dan Meta Analisis. Fak Kedokt Univ Udayana. 2012:1-16. 
http://files.figshare.com/101123/TEL

AAH_KRITIS_ARTIKEL_REVIEW

_SISTEMATIK_DAN_META_ANA

LISIS.pdf.

9. Sari NPWP, Fertanubun JFD, Mare YB, Fi SN. Literature review: Intervensi Keperawatan Terkini untuk Meningkatkan Pengetahuan dan Tindakan Masyarakat Dalam Pencegahan/Pengendalian Malaria. $J$ Hesti Wira Sakti. 2016;4(1):76-93. doi:10.1007/978-3-319-15741-2_2

10. Nurapriyanti I. FAKTOR - FAKTOR YANG MEMPENGARUHI STATUS GIZI BALITA DI POSYANDU KUNIR PUTIH 13 WILAYAH KERJA PUSKESMAS UMBULHARJO I KOTA YOGYAKARTA TAHUN 2015. digilib.unisayogya.ac.id. 2015. digilib.unisayogya.ac.id/1879/1/naska h publikasi IMA NURAPRIYANTI R.201410104238 pdf.2.pdf\%0D.

11. Rona Firmana Putri1, Delmi Sulastri2 YL. Faktor-Faktor yang Berhubungan dengan Status Gizi Anak Balita di Wilayah Kerja Puskesmas Nanggalo Padang. $J$ Kesehat Andalas. 2015;4(1). file:///D:/PENELITIAN DAN ABDIMAS/Jurnal Jumlah anak dan Status Gizi/Rona.pdf\%0D.

12. Agesti Labada AmatusYudi Ismanto Rina Kundre. HUBUNGAN KARAKTERISTIK IBU DENGAN
STATUS GIZI BALITA YANG BERKUNJUNG DI PUSKESMAS BAHU MANADO. eJournal Keperawatan (eKp). 2016; Volume 4 N. file:///D:/PENELITIAN DAN ABDIMAS/Jurnal Jumlah anak dan Status Gizi/Agesti labada.pdf\%0D.

13. Rina Nuraeni. Hubungan Antara Karakteristik Ibu dengan Status Gizi Balita di UPTD Puskemas Balida Kec Dawuan Kab Majalengka Tahun 2016. J Kesehat dan keperawatan Med AKPER YPIB Majalengka. 2017; Volume

III. file://D:/PENELITIAN DAN ABDIMAS/Jurnal Jumlah anak dan Status Gizi/Rina Nuraeni MEDISINA-Jurnal-Keperawatandan-Kesehatan-AKPER-YPIBMajalengkaVolume-III-Nomor-6Juli-2017.pdf\%0D.

14. Welly Febriza Zainul. Hubungan Tingkat Pengetahuan Ibu dan Paritas dengan Status Gizi Balita di Kelurahan Purus Wilayah Kerja Puskesmas Padang Pasir Tahun 2018. Repos Ris Kesehat Nas. 2018.

15. Oktarina Z, Sudiarti T. Faktor Risiko Stunting Pada Balita (24-59 Bulan) Di Sumatera. J Gizi dan Pangan. 2014;8(3):177. doi:10.25182/jgp.2013.8.3.177-180 
